\title{
Chronic low back pain: block vertebra
}

\author{
Darshpreet Kaur, ${ }^{1}$ Nidhi Billore, ${ }^{2}$ Gunjan Kumar, ${ }^{3}$ Puneet Aggarwal ${ }^{4}$
}

1Department of Physiotherapy, Bihar Neurodiagnostic Centre, Patna, Bihar, India

${ }^{2}$ RV College of Physiotherapy, Bangalore, Karnataka, India

${ }^{3}$ Department of Internal Medicine, Dr Ram Manohar Lohia Hospital, New Delhi, India

${ }^{4}$ Department of Internal Medicine, PGIMER \& Dr Ram Manohar Lohia Hospital, New Delhi, India

\section{Correspondence to} Dr Puneet Aggarwal, puneetaggarwal4u@gmail.com

\section{DESCRIPTION}

A 52-year-old woman came to our rehabilitation department with a history of chronic low back pain except for well-controlled depression and occasional pain killers for last 4 years. Examination revealed considerable postural asymmetry with right hip higher than left and right shoulder lower than left, paraspinal muscle fullness in the lumbar region, decreased lumbar lordosis, tenderness in L2-L5 lumbar vertebrae and in gluteal region. There was significant pain on lateral bending and spinal rotation which increased while coming from flexion to hyperextension. Manual muscle testing revealed weakness in abdominals, hip flexors (3/5) and quadriceps $(4 / 5)$. Straight leg raising test was positive bilaterally and so was the prone lumbar instability test.

X-Ray showed Grade 1 anterolisthesis (figure 1) of L3 over L4, block vertebrae of L4 and L5 and degenerative changes are predominantly involving $\mathrm{L} 5$ and S1 vertebrae.

Considering it to be a case of block vertebra with chronic low back pain with radiculopathy, she was educated about her problem and various pain radiating to both the legs. Her history was uneventful

relieving positions. Guidance was given on proper posture maintenance and body mechanics with regular strengthening exercises. Modalities like moist heat and cryotherapy were recommended to relax muscles and reduce pain. The presence of lumbar block vertebrae is less common, ${ }^{1}$ but if present, it results in premature degenerative changes owing to altered biomechanics. ${ }^{2}$ Thus early diagnosis of these anomalies and thorough workup will be helpful in establishing primary diagnosis and documenting long-term changes owing to these conditions. Also timely education of the patient to change life style can help keep various complications at bay.

\section{Learning points}

- Congenital blocked lumbar vertebra is a less common developmental disorder.

- Thorough workup of the patient is important to pin point affected areas.

- Patient education and life style modifications play a vital role.
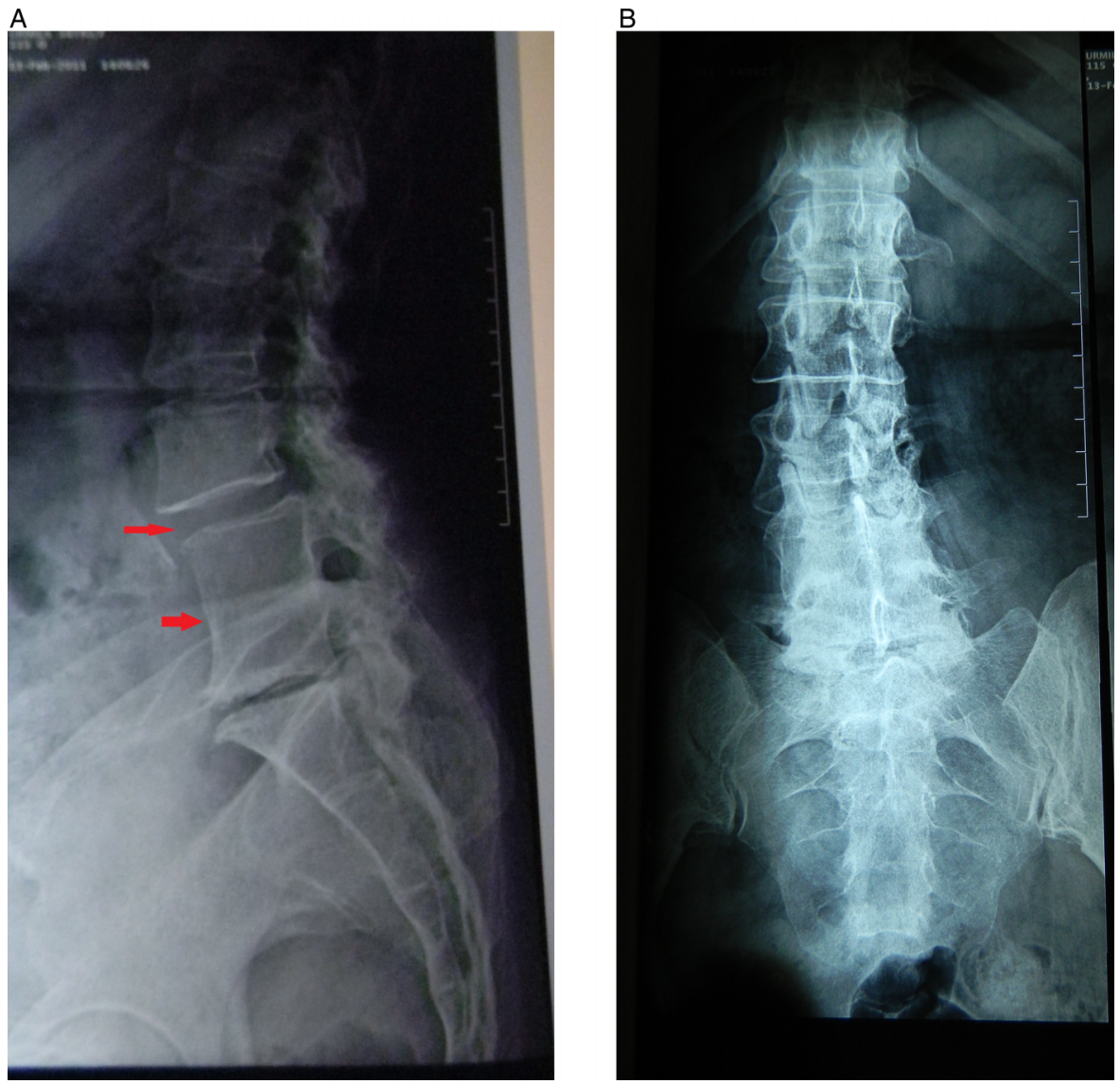

Figure 1 Grade 1 anterolisthesis of $L 3$ over L4, block vertebrae of $L 4$ and $L 5$ and degenerative changes are predominantly involving L5 and S1 vertebrae. 
Contributors DK supervised the overall patient management, NB helped in carrying out patient assessment, and PA and GK helped in differential diagnosis of the patient.

Competing interests None.

Patient consent Obtained.

Provenance and peer review Not commissioned; externally peer reviewed.

\section{REFERENCES}

1 Kumar R, Guinto FC, Madewell JE, et al. The vertebral body: radiographic configurations in various congenital and acquired disorders. Radiographics 1988;8:455-85.

2 Guebert GM, Rowe LJ, Yochum TR, et al. Congenital anomalies and normal skeletal variants. In: Yochum TR, LJ Rowe, Eds. Essentials of skeletal radiology. Baltimore: Lippincott Williams \& Wilkins, 2005:278-87.

Copyright 2013 BMJ Publishing Group. All rights reserved. For permission to reuse any of this content visit http://group.bmj.com/group/rights-licensing/permissions.

BMJ Case Report Fellows may re-use this article for personal use and teaching without any further permission.

Become a Fellow of BMJ Case Reports today and you can:

- Submit as many cases as you like

- Enjoy fast sympathetic peer review and rapid publication of accepted articles

- Access all the published articles

- Re-use any of the published material for personal use and teaching without further permission

For information on Institutional Fellowships contact consortiasales@bmjgroup.com

Visit casereports.bmj.com for more articles like this and to become a Fellow 